\title{
Special issue, "Kurile arc subduction zone: View of great earthquake generation and disaster mitigation of related phenomena"
}

\author{
Yuichiro Tanioka ${ }^{*}$, Naoki Uchida ${ }^{2}$, Aditya Riadi Gusman³ ${ }^{3}$ Masanobu Shishikura ${ }^{4}$ and Takuya Nishimura ${ }^{5}$
}

Various great earthquakes have occurred in the past along the Kurile subduction zone where the Pacific plate subducts along the Kurile Trench. The Headquarters for Earthquake Research Promotion, Japan, published a long-term evaluation report on the occurrence of large subduction earthquakes along the Kurile Trench (Headquarters of Earthquake Research Promotion 2018). They reported that the probability of a giant earthquake with a magnitude exceeding $M_{\mathrm{w}} 8.8$ along the Kurile trench in 30 years is between 7 and $40 \%$, as of 2021 . Mitigation of disasters due to the giant earthquake along the Kurile arc subduction zone has become one of urgent challenges in Japan. This special issue covers various researches concerning earthquake generation and postseismic processes, seismic wave attenuation, forecast of seismic activities, and mitigation of tsunami disasters in and around the subduction zone.

First, precise hypocenter estimation of micro-earthquakes along the Kurile subduction zone is a key to understand seismic activity and the stress field. Ichiyanagi et al. (2020) presented that the estimation error of hypocenter along the Kurile trench was significantly reduced using both Japanese and Russian data. In addition, Shiina et al. (2021) indicated that high-attenuation zones in the backarc mantle wedge controlled propagations of high-frequency S-wave later phases in addition to the scatterers in the forearc region.

*Correspondence: tanioka@sci.hokudai.ac.jp

${ }^{1}$ Institute of Seismology and Volcanology, Faculty of Science, Hokkaido University, Sapporo 060-0810, Japan

Full list of author information is available at the end of the article
Next, using precise micro-earthquake data, the stress field due to the Kurile subduction can be studied. Maeda et al. (2020) studied the spatiotemporal variation in stress from eastern Aomori to Tsugaru Strait using those data. Their results indicated that those variations reflected the effects of the upper-plate bending and the 2011 TohokuOki earthquake, and that the compressional stress caused by the Pacific plate was relatively weak. Using aftershock data of the 2018 Eastern Iburi earthquake, Susukida et al. (2018) studied the stress field in the aftershock area in the western boundary of the Hidaka Collision Zone. Their results showed that the reverse-fault-type stress field was predominant in this area.

Finally, forecast of future earthquake activities and precise tsunami forecast are challenges for disaster mitigation. Katsumata and Nakatani (2021) tested the seismic quiescence hypothesis through retrospective trials of alarm-based earthquake prediction in the Kurile-Japan subduction zone. Their conclusion is that there is a reasonable chance that their tested quiescence will pass the cross-validation test when more target earthquakes become available in the near future. Kano et al. (2020) developed an adjoint method assimilating GNSS time series data to optimize the frictional parameters that control the slip behavior on the fault. They applied the method to the observed GNSS time series for the first 15 days following the 2003 Tokachi-oki earthquake and found that the optimized frictional parameters quantitatively predicted the postseismic GNSS time series. Therefore, their data assimilation method is an effective evaluation method for assessing risks of subsequent earthquakes and for monitoring the recovery process of megathrust earthquakes. As a near-field tsunami 
forecasting method, Tanioka (2020) developed a method assimilating ocean-bottom pressure sensor network (S-net) without any information of earthquakes. The method was numerically tested for two large underthrust fault models, a giant earthquake $\left(M_{\mathrm{w}} 8.8\right)$ and the Nemuro-oki earthquake $\left(M_{\mathrm{w}} 8.0\right)$ models along the Kurile arc subduction zone. The results indicated that the method was applicable to the data at the S-net stations.

This special issue presents promising results for mitigation of disaster due to giant earthquakes along the Kurile arc subduction zone although some of researches are still primitive and also challenging. Continuation of studies is necessary to mitigate disaster due to future giant earthquakes. Most of researches presented in this special issue were supported by the Ministry of Education, Culture, Sports, Science and Technology (MEXT) of Japan, under "The Second Earthquake and Volcano Hazards Observation and Research Program".

\section{Authors' contributions}

YT, NU, AG, MS, and TN served as quest editors for this special issue. All authors read and approved the final manuscript.

\section{Competing interests}

The authors declare that they have no competing interests.

\section{Author details}

${ }^{1}$ Institute of Seismology and Volcanology, Faculty of Science, Hokkaido University, Sapporo 060-0810, Japan. ${ }^{2}$ Research Center for Prediction of Earthquakes and Volcanic Eruptions, Graduate School of Science, Tohoku University, Sendai 980-8578, Japan. ${ }^{3}$ GNS Science, Lower Hutt 5040, New Zealand. ${ }^{4}$ Research Institute of Earthquake and Volcano Geology, Geological Survey of Japan, National Institute of Advanced Industrial Science and Technology (AIST), 1-1-1 Higashi, Tsukuba, Ibaraki 305-8567, Japan. ${ }^{5}$ Research Center for Earthquake Prediction, Disaster Prevention Research Institute, Kyoto University, Gokasho, Uji, Kyoto 611-0011, Japan.

Received: 10 May 2021 Accepted: 11 May 2021

Published online: 07 June 2021

\section{References}

Headquarters of Earthquake Research Promotion (2018). Evaluations of occurrence potential of large earthquakes along the Kurile trench. https:// www.jishin.go.jp/main/chousa/kaikou_pdf/chishima3.pdf. Accessed 10 May 2021

Ichiyanagi M, Mikhaylov V, Kostylev D, Levin Y, Takahashi H (2020) Evaluation for hypocenter estimation error in the southwestern Kuril trench using Japan and Russia joint seismic data. Earth Planets Space 72:86. https:// doi.org/10.1186/s40623-020-01215-0

Kano M, Miyazaki S, Ishikawa Y, Hirahara K (2020) Adjoint-based direct data assimilation of GNSS time series for optimizing frictional parameters and predicting postseismic deformation following the 2003 Tokachioki earthquake. Earth Planets Space 72:159. https://doi.org/10.1186/ s40623-020-01293-0

Katsumata K, Nakatani M (2021) Testing the seismic quiescence hypothesis through retrospective trials of alarm-based earthquake prediction in the Kurile-Japan subduction zone. Earth Planets Space 73:100. https://doi. org/10.1186/s40623-021-01418-z

Maeda S, Matsuzawa T, Okada T, Katao H, Yoshida T, Kosuga M, Otsubo M (2020) Spatiotemporal variations in the stress field in the northeasternmost part of the NE Japan arc: constraints from microearthquakes. Earth Planets Space 72:117. https://doi.org/10.1186/s40623-020-01245-8

Shiina T, Katsumata K, Yomogida K, Kato A (2021) Attenuation contrast in mantle wedge across the volcanic front of northeastern Japan that controls propagations of high-frequency S-wave later phases. Earth Planets Space 73:33. https://doi.org/10.1186/s40623-021-01361-z

Susukida Y, Katsumata K, Ichiyanagi M, Ohzono M, Aoyama H, Tanaka R, Takada M, Okada K, Takahashi H, Sakai S, Matsumoto S, Okada T, Matsuzawa T, Hirano S, Yamanaka Y, Kosuga M, Katao H, Nagaoka A, Tsumura N, Ueno T, The Group for the Aftershock Observations of the 2018 Hokkaido Eastern Iburi Earthquake (2021) Focal mechanisms and the stress field in the aftershock area of 2018 the Hokkaido Eastern Iburi earthquake (MJMA = 6.7). Earth Planets Space 73:1. https://doi.org/10.1186/ s40623-020-01323-x

Tanioka Y (2020) Improvement of near-field tsunami forecasting method using ocean-bottom pressure sensor network (S-net). Earth Planets Space 72:132. https://doi.org/10.1186/s40623-020-01268-1

\section{Publisher's Note}

Springer Nature remains neutral with regard to jurisdictional claims in published maps and institutional affiliations.

\section{Submit your manuscript to a SpringerOpen ${ }^{\circ}$ journal and benefit from:}

- Convenient online submission

- Rigorous peer review

- Open access: articles freely available online

- High visibility within the field

- Retaining the copyright to your article

Submit your next manuscript at $\boldsymbol{\nabla}$ springeropen.com 